\title{
COMPARATIVE ANALYSIS OF CORPORATE GOVERNANCE PRACTICES IN FINANCIAL AND MANUFACTURING FIRMS IN NIGERIA \\ ADEGOKE Jonathan Funminiyi ${ }^{\star}$
}

Received date: 10/ 10/2018, Accepted date: 28/ 10/2018, online publication date: **/**/****,

\begin{abstract}
The study examined the key factors influencing corporate governance in Nigerian financial and manufacturing firms. It also examined the comparative level of compliance to the key factors of corporate governance between financial and manufacturing firms. The study adopted a descriptive survey research design. Primary data on corporate governance were collected through the administration of questionnaire. The study sample were selected using systematic random sampling technique. A total of 255 out of 270 respondents in the two sectors responded to the questionnaire and all the analyses were based on these 255 respondents. Data collected were analysed using descriptive statistics such as simple percentages, frequency counts and inferential statistics such as ANOVA. The results showed that out of the four key factors of corporate governance only the disclosure and transparency fully influences the level of compliance with effective corporate governance demonstrated by the firms under study and this applies to both financial/insurance firms and the manufacturing industries. ownership structure. Also there was no significant difference in the firms' compliance with board composition between financial and manufacturing firms $(\mathrm{t}=0.512, \mathrm{p}>0.05)$. However, significant differences existed in the firms' compliance with disclosure $(\mathrm{t}=-2.719 \mathrm{p}$ $<0.05)$ ownership structure $(\mathrm{t}=9.690, \mathrm{p}<0.05)$ and firm size $(\mathrm{t}=-$ 2.094, $\mathrm{p}<0.05)$.
\end{abstract}

$\star$ (Ph.D.), Department of Entrepreneurial Studies Federal University of Agriculture, Abeokuta. Nigeria, Email: niyiaction@gmail.com 
Keywords: Corporate Governance, Board of Directors, Disclosure, Ownership Structure.

JEL Code: G32, G34, O16.

Citation: ADEGOKE, J, F. (2018). Comparative Analysis Of Corporate Governance Practices In Financial And Manufacturing Firms In Nigeria. Journal of Finance and Corporate Governance, Vol., 2, No. 1: pp. 2140. (Jun 2018); ISSN: 2602-5655.

\section{Introduction}

The subject of corporate governance leapt to global business limelight from relative obscurity after a string of collapses of high profile companies. It has become one of the most topical issues in modern business world. It became an issue of international concern and debate in the early 1980s, through 1990s and has continued into the twenty-first century. Globally, corporate scandals and mismanagement of resources are still unfolding, involving high incidences of improper activities of managers' expropriating resources of firms at the ultimate expense of shareholders. Enron, the Houston-Texas based energy giant and Worldcom the telecom giant, shocked the business world with both the scale and age of their unethical and illegal operations. These organizations seemed to indicate only the tip of a dangerous iceberg. Corporate practices of many companies in the US came under attack of misappropriation, it appeared that the problem was far more wide spread. Large and trusted companies from Parmalat in Italy to the multinational newspaper group Hollinger Inc. Adephia Communication Company, Global Crossing Limited and Tyco International Limited cases significantly revealed deep rooted problems in their corporate governance. Even the prestigious New York Stock Exchange in the United State had to remove its director amidst outcry of the public over excessive compensation paid to staff (La Porta, Lopez and Shleifer, 2000).

Effective corporate governance by its nature is critical to all economic transactions especially in emerging and transition economies at varying levels of agency interactions, market institutional conditions that reduce informational imperfections and facilitate effective monitoring of agents impinging on the efficiency of investment shareholders and other stakeholders (Greuning and Bratanovic, 2003). The role of corporate governance is to prevent expropriation of investors by the agents (managers), to increase organizational performance and to prevent 
misappropriation and mismanagement of organizational resources. The weight of these primary functions of corporate governance has prompted re-examination and scrutiny of the existing corporate governance practices and the enactment of codes of best practices in most modern businesses.

The key elements of sound corporate governance include well-articulated corporate strategy against which the overall success and the contribution of individuals can be measured; setting and enforcing clear assignment of responsibilities; decision making, authority and accountabilities; a strong financial risk management, corporate disclosure and transparency, adequate internal control system (including internal and external audit functions); functional process design with necessary checks and balances; corporate values, codes of conduct and standard for appropriate behaviour; financial and managerial incentives to act in an appropriate manner offered to the board, management and employees, including compensation, promotion and penalties.

In some countries (such as Iran and Kuwait) banks and many manufacturing companies are part of larger family - controlled business groups sometimes abused as a tool for maximizing the family interests rather than the interests of all stakeholders. In other cases where private ownership concentration was not allowed, the banks and insurance were heavily interfered with and controlled by the government even without any ownership share (Zahra 1996 and Yeung 2000). Without doubt, in either case, corporate governance was very poor. The symbolic relationship between the government, banks and big businesses also contributed to the maintenance of tax prudential regulation, weak bankruptcy codes and poor corporate governance rules and regulations (Ahmad and Mansur, 2012). Many researchers believed that Asian crisis in 1997 and 1998 was due to poor corporate governance (Mohammed, 2006; Haat, Rahman and Mahenthiran, 2008; Ponnu, 2008).

In Nigeria, before the consolidation exercise, the banking industry has about 89 active players whose overall poor performance led to reduced customers' confidence. There was lingering distress in the country, the supervisory structures were inadequate and there were cases of official recklessness and ethical abuse amongst the managers and directors (Akpan, 2007). Some institutions documented for this kind of collapse include Alpha Merchant Banks Ltd, Savannah Bank Plc, Societe Generate Bank Ltd, Intercontinental Bank, Oceanic Bank Plc among others in Nigeria. In Kenya, the 
Continental Bank Kenya Ltd, Capital Finance Ltd, Consolidated Bank of Kenya and Trust Bank of Kenya among others (Akpan, 2007).

In the manufacturing sector the corporate problems of Nigerian companies include lack of transparency and accountability, ineffective control and monitoring which greatly reduces investors' confidence in the management. For example, in the UAC's audit report for 1998, attempt by the directors to sell company's properties to themselves was rejected by shareholders. Also in Guinness Annual General Meeting in 1999, an attempt by the chairman of the board to bring about change of auditors without due process was rebuffed (Shonubi, 2003).

None of the earlier studies found was focused on the key factors influencing corporate governance in financial and manufacturing firms, given that corporate governance practices differ across industries within the same economy. Hence, this study compared the key factors influencing corporate governance in financial and manufacturing firms and their level of compliance to these factors to fill the gap on lessons that can be learned from different corporate governance practices and organizational culture.

This study will not only provided empirical information on the comparative level of compliance demonstrated by financial and manufacturing firms with regards to effective corporate governance practices, it will also specifically identify those factors in the two types of firms.. It will also provide a platform for the measurement of corporate governance and adequate techniques of assessing governance to practitioners, investors and the general public and gives an insight on new research areas to be explored for an improved corporate governance practices in Nigeria It is against the aforementioned gaps that the following research questions were raised and answered:

(i) What are the key factors influencing corporate governance in financial and manufacturing firms?

(ii) What is the comparative level of compliance to the key factors of corporate governance

between financial and manufacturing firms?

To effectively explore possible relationship that may exist among the variables, the following hypothesis was tested: 
Vol. 2, No. 1 (Jun 2018); ISSN: 2602-5655

(i) There is no significant difference in the firms' compliance with the key factors of corporate governance between financial and manufacturing firms.

\section{Methodology}

The study adopted descriptive survey research design as it examined the key factors influencing corporate governance in financial and manufacturing firms under investigation. The survey method was used to generate primary data from selected financial and manufacturing companies.

Nineteen commercial banks, forty-one insurance companies and four hundred and fifty three manufacturing firms having their corporate headquarters located in southwest Nigeria constituted the population for this study. Fifty percent of the populations of the insurance companies (that is, twenty-one) were selected using simple random technique (lottery method) in addition to the entire population of nineteen banks. On manufacturing firms, the sector was divided into sixteen subsectors which include Appliances Equipment; Automobile and Tyres; Building Materials; Chemicals and Pharmaceuticals; Conglomerates, Food, Beverages and Agro-Allied Products; Engineering and Construction; Foam, Mattresses and Beddings; Gases; Motor Boats; Metal Foundries; Metals Packaging and Caps; Paints; Paper and Stationery; Plastics; Steel Mills; and Textiles. Ten percent of the populations in each of the sixteen sub-sectors, totaling fifty were randomly selected. This is justified with the minimum acceptable sample sizes (Gay in Zulueta and Costales, 2003 cited in Dionco-Adetayo, 2011). From each of the chosen financial and manufacturing firms, three top management staff who are in position to give information on corporate governance was purposively selected, resulting in a total of two hundred and seventy respondents.

Data were collected through primary and secondary sources. Primary data gathering were through questionnaire and secondary data from the annual reports and accounts of the selected firms. One of the research instruments used for this study was a questionnaire adapted from Organization of Economic Cooperation and Development (OECD, 2006) designed to reflect the determinants for effective corporate governance which has been used and put forth by the OECD. The OECD guidelines make a useful suggested framework, covering five important areas of governance: the firm size, ownership structure, board composition, cultural and historical factors as well as disclosure and transparency. Other relevant items were 
gathered from PricewaterhouseCooper LLP (2009) which has been used and tested in some African and Asian countries. The two were integrated together and slightly modified to suite the set objectives of the current study and accommodate cultural differences. The instrument was divided into four sections. Each section was designed to collect information on the following variables.

(a) Socio-demographic information, firm size and ownership structure.

(b) Corporate governance compliance

(c). Board composition

(d). Disclosure and transparency

Other instruments were the Annual Reports and Accounts of the selected firms which were used to collect relevant secondary data on board composition.

The research instrument was presented to experts that verified its content validity. Test-retest reliability method on a pilot study using thirty copies of the questionnaire yielded reliability co-efficient of 0.724 that is significant at 0.05 level $(n=30, r=0.724, p<0.05)$ to confirm the reliability of the instrument.

Data collected were analyzed using descriptive statistics such as percentages, frequency counts and relative significance index (RSI) and inferential statistics which include correlation analysis, t-test analysis, analysis of variance and factor analysis through the use of Statistical Package for the Social Sciences (SPSS) version 18.0

\section{Results}

Research Question 1: What are the key factors influencing corporate governance in financial and manufacturing firms?

To investigate the key factors that influence corporate governance in financial and manufacturing firms, the key factors (firm size, ownership structure, board composition and disclosure) were cross-tabulated with the firms' compliance with effective corporate governance practices. For firm size, two items in the section A of the questionnaire were employed - item 10 (the number of employees in the firm) and item 11 (Firm Annual turn-over). As can be seen in table 4.1, none of the respondents indicated that his/her firm had $11-30$ employees and also that their annual turn-over is less than $\$ 250,000$. Consequently, only six categories were possible as follows:

1. Firms which had 10 or less employees with annual turnover of 5 million or less were said to be very small firms 
Vol. 2, No. 1 (Jun 2018); ISSN: 2602-5655

2. Firms which had 31 to 50 employees with annual turnover of 5 million or less were said to be small firms

3. Firms which had more than 50 employees with annual turnover of 5 million or less were said to be moderately sized firms

4. Firms which had 10 or less employees with annual turnover of more than 5 million were said to be fairly large firms

5. Firms which had 31 to 50 employees with annual turnover of more than 5 million were said to be quite large firms

6. Firms which had more than 50 employees with annual turnover of more than 5 million were said to be very large firms

These categories were then cross-tabulated with their levels of compliance with effective corporate governance and the result is presented in table 4.6.

Table 4.6: Influence of Firm Size on Compliance with Effective Corporate Governance

\begin{tabular}{|c|c|c|c|c|c|c|c|c|c|c|}
\hline \multirow[b]{2}{*}{$\begin{array}{l}\text { Level of } \\
\text { Compliance }\end{array}$} & \multicolumn{4}{|c|}{ Financial Institution/Insurance } & \multicolumn{4}{|c|}{ Manufacturing Industries } & \multirow[b]{2}{*}{$\begin{array}{l}\text { Very } \\
\text { large }\end{array}$} & \multirow[b]{2}{*}{ Total } \\
\hline & $\begin{array}{r}\text { Sm } \\
\text { all }\end{array}$ & $\begin{array}{c}\text { Moder } \\
\text { ate }\end{array}$ & $\begin{array}{c}\text { Fairly } \\
\text { large }\end{array}$ & $\begin{array}{l}\text { Very } \\
\text { large }\end{array}$ & Total & Small & $\begin{array}{c}\text { Mode } \\
\text { rate }\end{array}$ & $\begin{array}{c}\text { Fairly } \\
\text { large }\end{array}$ & & \\
\hline Poor level & 0 & 0 & 0 & 29 & 29 & 0 & 0 & 0 & 17 & 17 \\
\hline Fair & 0 & 4 & 3 & 71 & 78 & 1 & 0 & 0 & 117 & 118 \\
\hline Good & 0 & 0 & 0 & 7 & 7 & 0 & 0 & 0 & 6 & 6 \\
\hline Total & 0 & 4 & 3 & 107 & 114 & 1 & 0 & 0 & 140 & 141 \\
\hline
\end{tabular}

Source: Field Survey (2013)

The table shows the influence of firm size on corporate governance in financial and manufacturing firms. It can be seen from the table that most of the financial/insurance institutions were large firms and were mostly fair in their compliance with effective corporate governance practices. None of them were found to be small at any level of compliance. A similar result is also visible among the manufacturing industries where most of them are also large and are mostly said to be fair in their compliance with effective corporate governance practices. It can therefore be concluded that firm size has partially influenced the level of compliance of both financial/insurance institutions and those of the manufacturing industries with corporate governance.

For ownership structure, three items were also employed to determine the kind of ownership structure of each of the firms - Item 12 (proportion of corporate 
Vol. 2, No. 1 (Jun 2018); ISSN: 2602-5655

shareholders), item 13 (proportion of block shareholders and item 14 (proportion of individual shareholders). These items were subjected to cluster analysis to categorize the responses. It yielded three categories:

1. Moderate percentage of corporate shareholders, moderate percentage of block shareholders and \& moderate percentage of individual shareholders

2. Low percentage of corporate shareholders, moderate percentage of block shareholders and \& High percentage of individual shareholders

3. High percentage of corporate shareholders, moderate percentage of block shareholders and \& low percentage of individual shareholders .

These categories were then cross-tabulated with their levels of compliance with effective corporate governance and the result is presented in table 4.7 which shows the influence of firm size on corporate governance in financial and manufacturing firms. It can be seen from the table that $74 \%$ of the financial/insurance institutions were concentrated under "High \% corporate, moderate \% block \& low \% individual" and were mostly fair in their compliance with effective corporate governance practices. A larger percentage of the firms was found to possess fair level of corporate governance compliance.

Table 4.7: Influence of Firm Ownership on Compliance with Effective Corporate Governance

\begin{tabular}{|c|c|c|c|c|c|c|c|c|}
\hline \multirow[b]{2}{*}{ 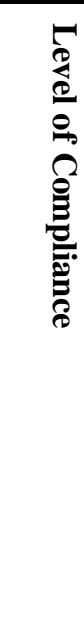 } & \multicolumn{4}{|c|}{ Financial Institution/Insurance } & \multicolumn{4}{|c|}{ Manufacturing Industries } \\
\hline & 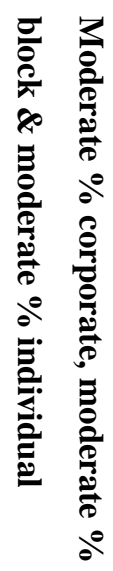 & 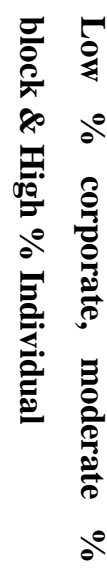 & 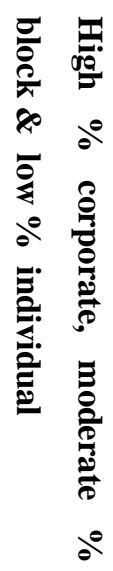 & Total & 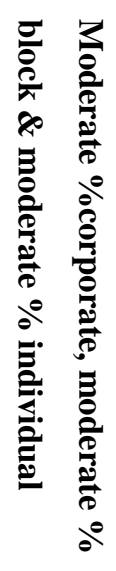 & 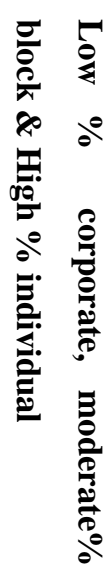 & 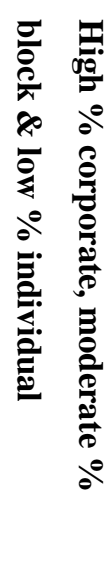 & Total \\
\hline Poor & 1 & 6 & 22 & 29 & 1 & 9 & 7 & 17 \\
\hline Fair & 3 & 18 & 57 & 78 & 28 & 70 & 20 & 118 \\
\hline Good & 0 & 2 & 5 & 7 & 1 & 5 & 0 & 6 \\
\hline Total & 4 & 26 & 84 & 114 & 30 & 84 & 27 & 141 \\
\hline
\end{tabular}

Source: Field Survey (2013) 
Vol. 2, No. 1 (Jun 2018); ISSN: 2602-5655

A similar result is also visible among the manufacturing industries where $60 \%$ were owned by "Low \% corporate, moderate\% block \& High \% individual". They were also mostly said to be fair in their compliance with effective corporate governance practices.

It can therefore be concluded that firm ownership has influenced neither the level of compliance of financial/insurance institutions nor those of the manufacturing industries understudy with corporate governance.

For board composition, Items in section $\mathrm{C}$ of the questionnaire were scored as presented in table 4.8. The resulting scores were cumulated to constitute a measure of board composition. The maximum score obtainable on this measure was 60 while the minimum possible was 16 . The range therefore was 44 . Those who scored less than $40 \%$ of the range that is 34 or below were regarded as having unhealthy board composition while those who scored above 34 were said to be experiencing healthy board composition.

\section{Table 4.8: Scoring Procedure for Board Composition}

\begin{tabular}{|c|c|}
\hline Item & $\begin{array}{l}\text { "Less than } 20 \% " \text { or "all of them" was scored 1, "Less than } 20 \% " \text { or "50 to } \\
75 \% " \text { was scored } 2 \text { and } 20 \text { to } 50 \% \text { was scored } 3\end{array}$ \\
\hline Items 3,6 and 7 & $\begin{array}{l}\text { None was scored } 1 \text {, "Less than } 20 \% "=2,20 \text { to } 50 \%=3, " 50 \text { to } 75 \% "=4 \text { and } \\
\text { "all of them" = } 5\end{array}$ \\
\hline Items 8 & $\begin{array}{l}\text { None was scored } 5 \text {, "Less than } 20 \% "=4,20 \text { to } 50 \%=3, " 50 \text { to } 75 \% "=2 \text { and } \\
\text { "all of them" }=1\end{array}$ \\
\hline
\end{tabular}

Items $14,15,16, \quad$ "Always" $=1$, sometimes $=2$, Seldomly $=3$, "Never" $=4$, "I do not notice" $=4$ $17,18,19$ and 20

\footnotetext{
Source: Field Survey (2013)

These categories were given a descriptive analysis and the result is presented in table 4.9 which shows the board composition of the financial and manufacturing firms under study. It can be seen from the table that most of the firms (83.9\%) were said to have healthy board composition, although the greater percentage of the firms possessing healthy board composition were manufacturing firms $(43.9 \%)$ and also the greater of firms possessing unhealthy board composition (11.4\%).

This distribution was then cross-tabulated with the level of compliance with corporate governance and the result is presented in table 4.10 which shows the influence of board composition of the firms under study on their compliance with effective corporate governance.
} 
Vol. 2, No. 1 (Jun 2018); ISSN: 2602-5655

Table 4.9: Board Composition of the Financial and Manufacturing Firms Under Study

\begin{tabular}{lccc}
\hline Typeorg & \multicolumn{2}{c}{ Type of Board Composition } & Total \\
& Unhealthy Board Composition & $\begin{array}{l}\text { Healthy Board } \\
\text { Composition }\end{array}$ & \\
\hline Fin/Insurance & $12(4.7 \%)$ & $102(40.0 \%)$ & $114(44.7 \%)$ \\
Manufacturing & $29(11.4 \%)$ & $112(43.9 \%)$ & $141(55.3 \%)$ \\
Total & $41(16.1 \%)$ & $214(83.9 \%)$ & $255(100.0 \%)$ \\
\hline
\end{tabular}

Source: Field Survey (2013)

Table 4.10: Influence of Board Composition of the Firms on Compliance with Effective Corporate Governance

\begin{tabular}{lcccccc}
\hline $\begin{array}{l}\text { Level of } \\
\text { Complian } \\
\text { ce }\end{array}$ & $\begin{array}{c}\text { Financial Institution/Insurance } \\
\text { Unhealthy } \\
\text { Board } \\
\text { Composition }\end{array}$ & $\begin{array}{c}\text { Healthy Board } \\
\text { Composition }\end{array}$ & Total & $\begin{array}{c}\text { Manufacturing Industries } \\
\text { Unhealthy } \\
\text { Board } \\
\text { Composition }\end{array}$ & $\begin{array}{c}\text { Healthy Board } \\
\text { Composition }\end{array}$ & Total \\
\hline Poor level & 4 & 25 & 29 & 2 & 15 & 17 \\
Fair & 8 & 70 & 78 & 26 & 92 & 118 \\
Good & 0 & 7 & 7 & 1 & 5 & 6 \\
Total & 12 & 102 & 114 & 29 & 112 & 141 \\
\hline
\end{tabular}

Source: Field Survey (2013)

It can be seen that most of the firms possess fair level of compliance and were mostly healthy across the two types of firms and can be concluded that board composition did not influence the level of compliance of financial and manufacturing firms with effective corporate governance.

For level of disclosure, the section D of the questionnaire was scored in such a way that a "never" response was scored 1, while a "mild extent" response was scored 2 and an "appreciable extent" response was scored 3. Also a "great extent" response was scored 4. The resulting scores were cumulated to constitute a measure of disclosure and transparency in the firm. The maximum score on the measure was 56 while the minimum score was 14 . The scores were categorized in such a way that any score lower than 29 is said to be for low level of disclosure while scores of 29 to 42 were said to be for moderate level of disclosure and any score greater than 42 was said to be high level of disclosure and transparency in the firm. 
Vol. 2, No. 1 (Jun 2018); ISSN: 2602-5655

These categories were cross-tabulated with the firm's level of compliance with effective corporate governance and the result is presented in table 4.11 which shows the influence of the disclosure and transparency available in the firms on their level of compliance with effective corporate governance practices. It can be seen from the table that the higher the level of disclosure in the firms (both financial institution and manufacturing industries) the better the level of compliance with corporate governance practices. It can then be concluded that the level of disclosure and transparency available in the firm has a positive influence on the firm's compliance with corporate governance practices.

In general, it can be concluded that out of the four key factors of corporate governance only the disclosure and transparency fully influences the level of compliance with effective corporate governance demonstrated by the firms under study and this applies to both financial/insurance firms and the manufacturing industries.

Table 4.11: Influence of Disclosure in the Firms on Compliance with Effective Corporate Governance

\begin{tabular}{|c|c|c|c|c|c|c|c|c|c|c|c|}
\hline \multirow[b]{2}{*}{$\frac{\varrho}{\stackrel{0}{0}}$} & \multirow[b]{2}{*}{$\begin{array}{l}\stackrel{5}{0} \\
\stackrel{0}{0} \\
\stackrel{\varrho}{\varrho}\end{array}$} & \multicolumn{5}{|c|}{ Financial Institution/Insurance } & \multicolumn{5}{|c|}{ Manufacturing Industries } \\
\hline & & 5 & $\begin{array}{l}3 \\
\frac{2}{0} \\
\frac{9}{0} \\
\frac{0}{0}\end{array}$ & 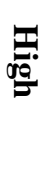 & & $\overrightarrow{\vec{\theta}}$ & לั) & $\begin{array}{l}\frac{3}{8} \\
\frac{0}{0} \\
\frac{0}{0} \\
\frac{0}{6}\end{array}$ & 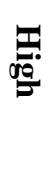 & & $\overrightarrow{\overrightarrow{0}}$ \\
\hline & 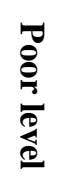 & $\begin{array}{l}\text { Oे } \\
\text { io } \\
\text { do }\end{array}$ & $\begin{array}{l}\vec{J} \\
\underset{\vec{t}}{\dot{0}} \\
d^{9}\end{array}$ & $\begin{array}{l}= \\
\text { పo } \\
\text { aे }\end{array}$ & & 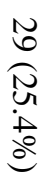 & 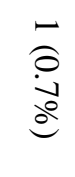 & $\stackrel{\vec{\partial}}{\stackrel{0}{j}}$ & $\underset{\stackrel{a}{+}}{\stackrel{a}{d}}$ & & 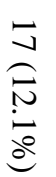 \\
\hline & 苛. & $\begin{array}{l}0 \\
\stackrel{0}{0} \\
e^{Q}\end{array}$ & $\begin{array}{l}\vec{\infty} \\
\underset{\bar{c}}{\infty} \\
\infty \\
d^{\infty}\end{array}$ & 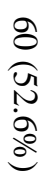 & & $\begin{array}{l}\stackrel{\infty}{\infty} \\
\hat{a} \\
\stackrel{+}{a} \\
\stackrel{d}{d}\end{array}$ & $\begin{array}{l}0 \\
\stackrel{0}{0} \\
\text { da }\end{array}$ & 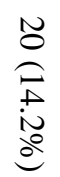 & $\begin{array}{l}\circ \\
\hat{a} \\
\dot{b} \\
\text { in } \\
j^{d}\end{array}$ & $\begin{array}{l}\stackrel{\infty}{\infty} \\
\stackrel{\vec{d}}{d^{d}}\end{array}$ & $\Xi$ \\
\hline & $\begin{array}{l}\text { वे } \\
\vdots\end{array}$ & $\begin{array}{l}\stackrel{0}{0} \\
\stackrel{0}{d}\end{array}$ & $\begin{array}{l}\stackrel{0}{a} \\
\stackrel{a}{d}\end{array}$ & $\underset{2}{2}$ & & $\frac{\sqrt{2}}{a^{\circ}}$ & $\begin{array}{l}\stackrel{0}{0} \\
\text { a } \\
\text { de }\end{array}$ & $\begin{array}{l}\stackrel{0}{0} \\
\stackrel{0}{0}\end{array}$ & $\underset{\stackrel{a}{+}}{\stackrel{a}{d}}$ & & $\underset{\stackrel{a}{\dot{d}}}{\stackrel{a}{d}}$ \\
\hline & $\overrightarrow{\vec{\theta}}$ & $\begin{array}{l}\overrightarrow{\hat{o}} \\
\dot{0} \\
\text { do }\end{array}$ & $\begin{array}{l}\tilde{u}^{w} \\
\stackrel{\omega}{0} \\
\stackrel{\vec{J}}{d^{d}}\end{array}$ & $\begin{array}{l}\sqrt{\infty} \\
\hat{\alpha} \\
\infty \\
\vec{d} \\
d^{a}\end{array}$ & $\begin{array}{l}\hat{\overline{8}} \\
\dot{8} \\
\dot{8}\end{array}$ & $\vec{\nabla}$ & $\begin{array}{l}\overrightarrow{0} \\
\stackrel{0}{d} \\
\mathfrak{d}\end{array}$ & $\begin{array}{l}\stackrel{w}{\circ} \\
\stackrel{N}{N} \\
\stackrel{\omega}{d^{Q}}\end{array}$ & $\begin{array}{l}\bar{\sigma} \\
\stackrel{0}{0} \\
0\end{array}$ & $\begin{array}{l}\widehat{\vec{\theta}} \\
\dot{0} \\
\dot{0}\end{array}$ & $\Xi$ \\
\hline
\end{tabular}

Source: Field Survey (2013) 
Vol. 2, No. 1 (Jun 2018); ISSN: 2602-5655

Research Question 2: What is the comparative level of compliance to the key factors of corporate governance between financial and manufacturing firms?

To determine the comparative level of compliance to the key factors of corporate governance between financial and manufacturing firms, the levels of compliance to the key factors (firm size, ownership structure, board composition and disclosure) were compared between financial and manufacturing firms and the result is presented in table 4.18

Table 4.18: Comparative Level of Compliance to the Key Factors of Corporate Governance Between Financial and Manufacturing Firms

\begin{tabular}{|c|c|c|c|c|}
\hline \multirow[t]{2}{*}{ Variables } & \multirow[t]{2}{*}{ Levels } & \multicolumn{2}{|c|}{ Typeorg } & \multirow[t]{2}{*}{ Total } \\
\hline & & Fin/Insurance & Manufacturing & \\
\hline \multirow[t]{7}{*}{ Firm Size } & Small & $0(0 \%)$ & $1(0.4 \%)$ & $1(0.4 \%)$ \\
\hline & Moderate & $4(1.6 \%)$ & $0(0 \%)$ & $4(1.6 \%)$ \\
\hline & Fairly large & $3(1.2 \%)$ & $0(0 \%)$ & $3(1.2 \%)$ \\
\hline & Very large & $107(42.0 \%)$ & $140(54.9 \%)$ & 247 \\
\hline & & & & $(96.0 \%)$ \\
\hline & Total & $114(44.7 \%)$ & $141(55.3 \%)$ & 255 \\
\hline & & & & $(100.0 \%)$ \\
\hline Ownership & Moderate $\%$ & $4(1.6 \%)$ & $30(11.8 \%)$ & $34(13.3 \%)$ \\
\hline \multirow[t]{11}{*}{ Structure } & Corporate Moderate & & & \\
\hline & \% Block \& Moderate & & & \\
\hline & $\%$ Individual & & & \\
\hline & Low \% Corporate & $26(10.2 \%)$ & $84(32.9 \%)$ & 110 \\
\hline & moderate $\%$ Block \& & & & $(43.1 \%)$ \\
\hline & High \% Individual & & & \\
\hline & High \% Corporate & $84(32.9 \%)$ & $27(10.6 \%)$ & 111 \\
\hline & Moderate \% Block & & & $(43.5 \%)$ \\
\hline & \& Low \% Individual & & & \\
\hline & Total & $114(44.7 \%)$ & $141(55.3 \%)$ & 255 \\
\hline & & & & $(100.0 \%)$ \\
\hline Board & Unhealthy Board & $12(4.7 \%)$ & $29(11.4 \%)$ & $41(16.1 \%)$ \\
\hline \multirow[t]{5}{*}{ Composition } & Composition & & & \\
\hline & Healthy Board & $102(40.0 \%)$ & $112(43.9 \%)$ & 214 \\
\hline & Composition & & & $(83.9 \%)$ \\
\hline & Total & $114(44.7 \%)$ & $141(55.3 \%)$ & 255 \\
\hline & & & & $(100.0 \%)$ \\
\hline Level of & Low & $1(.4 \%)$ & $1(.4 \%)$ & $2(.8 \%)$ \\
\hline
\end{tabular}


Vol. 2, No. 1 (Jun 2018); ISSN: 2602-5655

\begin{tabular}{lllll}
\hline Disclosure & Moderate & $35(13.7 \%)$ & $30(11.8 \%)$ & $65(25.5 \%)$ \\
& High & $78(30.6 \%)$ & $110(43.1 \%)$ & 188 \\
& & & $(73.7 \%)$ \\
& Total & $114(44.7 \%)$ & $141(55.3 \%)$ & 255 \\
& & & $(100.0 \%)$ \\
\hline
\end{tabular}

Source: Field Survey (2013)

The table shows that manufacturing firms constituted a greater percentage (54.9\%) of companies with large firm size than the financial institutions (42.0\%). They also constitute a greater percentage (32.9\%) of firms demonstrating "Low percentage of corporate shareholders, moderate percentage of block shareholders \& High percentage of individual shareholders" than what was demonstrated by financial institutions (10.2\%). Also, the manufacturing firms represented a greater percentage (43.9\%) of firms that demonstrated healthy board composition than the financial institutions (40.0\%). Considering the level of disclosure, there was a greater proportion of manufacturing firms (43.1\%) among those who exhibited high level of disclosure that the financial institutions (30.6\%), however at the moderate of disclosure, more financial institutions can be found.

It can therefore be concluded that manufacturing industries demonstrated better levels of compliance to the key factors of corporate governance between financial and manufacturing firms and this may have accounted for their better level of compliance with corporate governance principles than financial institutions.

Hypothesis 1: There is no significant difference in the firms' compliance with the key factors of corporate governance between financial and manufacturing firms.

To determine the significant difference in the firms' compliance with the key factors of corporate governance between financial and manufacturing firms, the score of each of the respondents from firms that adopted corporate governance practices under each of the key factors were subjected to independent t-test analyses using the type of organization (financial/insurance or manufacturing) as the differentiating variable. The result is presented in table 4.19 which presents the differences in the firms' compliance with the key factors of corporate governance between financial and manufacturing firms. 
Vol. 2, No. 1 (Jun 2018); ISSN: 2602-5655

Table 4. 19: Differences in the Firms' Compliance with the Key Factors of Corporate Governance Between Financial and Manufacturing Firms

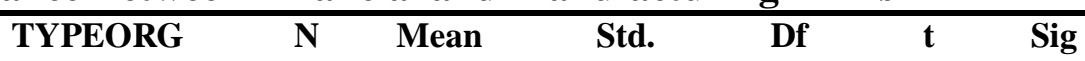

Deviation

\begin{tabular}{llcccccc}
\hline Board Composition & Fin/Insurance & 114 & 42.0351 & 5.42516 & 253 & 0.512 & 0.609 \\
& Manufacturing & 141 & 41.6454 & 6.74021 & & & \\
Disclosure & Fin/Insurance & 114 & 45.0614 & 6.66955 & 253 & -2.719 & 0.007 \\
& Manufacturing & 141 & 47.1631 & 5.66899 & & & \\
Ownership & Fin/Insurance & 114 & 2.70 & .531 & 253 & 9.690 & 0.000 \\
Structure & Manufacturing & 141 & 1.98 & .638 & & & \\
Firm Size & Fin/Insurance & 114 & 5.8421 & .63216 & 253 & -2.094 & 0.037 \\
& Manufacturing & 141 & 5.9716 & .33686 & & & \\
\hline Source: Fin
\end{tabular}

Source: Field Survey (2013)

It can be seen from the table that there is no significant difference in the firms' compliance with board composition between financial and manufacturing firms $(\mathrm{t}=$ $0.512, \mathrm{p}>0.05)$. However, significant differences existed in the firms' compliance with disclosure $(\mathrm{t}=-2.719 \mathrm{p}<0.05)$ ownership structure $(\mathrm{t}=9.690, \mathrm{p}<0.05)$ and firm size $(\mathrm{t}=-2.094, \mathrm{p}<0.05)$. Also manufacturing firms scored higher on disclosure (47.16) and firm size (5.97) than financial/insurance institution (45.06 and 5.84 respectively), financial institution/insurance firms (2.70) were better in terms of ownership structures than manufacturing firms (1.98). The needs for firms' compliance with these key factors of corporate governance by financial and manufacturing firms were entrenched in the necessary statutes.

\section{Discussion of Findings}

This study examined the key factors that influence corporate governance in both sectors, it was found that firm size partially influence the level of compliance of both financial and manufacturing firms with corporate governance, this is in agreement with Ettredge, Johnstone, Stone and Wan (2011) also found that firm size is positively associated with the quality of corporate governance and negatively associated with the disclosure of certain types of bad news. Ariff, Ibrahim and Othman, (2007) also found in their study that firm size has a strong influence with corporate governance ratings. Also, Ben-Amar and Ameur (2006), and Khanchel (2007) found that firm size has a positive influence on the corporate governance quality indicating that the larger the firm size, the better the corporate governance quality (Hartono, Subroto, Djumahir and Irianto, 2013). 
On that of ownership structure it was found that it has influenced neither the level of compliance of financial nor those of manufacturing firm under study with corporate governance. This finding is in agreement with those of researchers that posited the existence of an intrinsic relationship between corporate performance and the ownership structure (family or other) in a single company (Nader, 2010) and highlighted four key factors in determining the ownership structure of a company which in turn impacts the company's performance to include geographical location, tax systems, industrial development and cultural characteristics.

Zhuang (1999) argue that ownership structure is one of the most important factors in shaping the corporate governance system of any country. He asserted that the degree of ownership concentration in a firm determines how power is distributed between its shareholders and managers and that when ownership is dispersed, shareholding control tends to be weak because of poor shareholder monitoring.

However, Lazareva, Rachinsky and Stepanov (2010) posit that the relationship between ownership structure and corporate governance that was found across the three countries studied were most likely related to the differences in the legal framework and institutional environment in the countries.

For board compositions, it was concluded that it did not influence the level of compliance of financial nor manufacturing with effective corporate governance. This finding is in consonance with studies that common assessments of board composition are usually, insider/outsider director ratio, executive/non-executive directors ratio, age and gender diversity among board members and board size (Akhalumeh, Ohiokha and Ohiokha, 2011). Omoye and Eriki (2013) reviewed some empirical findings on ethnic diversity in the composition of company boards of directors. For instance, Watson, Kumar and Michaelsen, (1993) indicated that diversity results in greater knowledge, creativity and innovation and thus, organizations tend to become more competitive. In addition, improvement in decision making at strategic level can also be seen in the presence of diversity (Bantel, 1993). Also, both educational and cognitive diversity are positively correlated with organizational performance (Simons and Pelled, 1999). Siciliano (1996) found that board diversity paves a way for positive results in performance.

Cultural heterogeneity results in issue-based conflict which in turn enhances greater organizational performance. Heterogeneity is positively linked to better 
problem solving and offering creating solutions (Michael \& Hambrick, 1992). Hence, diversity is positively related to performance.

On the level of disclosure it was concluded that the level of disclosure and transparency available in the firm has a positive influence on the firm's compliance with corporate governance practices. In general, it can be concluded that out of the four key factors of corporate governance only disclosure and transparency fully influence the level of compliance with effective corporate governance demonstrated by the firm under study and this applies to both financial and manufacturing firms.

This finding agree with that of the Association of Chartered Certified Accountants (2009), which observed that the strength of an organisation's corporate governance systems and the quality of public disclosures are becoming increasingly important to business, because, as sustainability becomes an ever more critical business issue, stakeholders are paying more attention to what is reported and how it is reported. It concluded that organisations that see disclosing information on corporate governance as an opportunity to be transparent with stakeholders can potentially use reporting processes to drive improvements to their structures and processes internally.

Shelton-Colby (2000) hinged the development of corporate governance on transparency and disclosure that if corporate governance does not improve, the domestic equity market will not develop, however, improving transparency and disclosure of financial and non-financial information is key in this respect. Even the OECD (2013) posits that in corporate governance, accountability requires appropriate rules and regulations, in which disclosure is the most important element.

In comparing the level of compliance to the key factors of corporate governance between financial and manufacturing firms, it was concluded that manufacturing firms had a better level of compliance with corporate governance principle than financial institutions. This finding stressed the importance of corporate governance in corporate administration, given the dominant involvement of corporate governance breach in most of the corporate failures witnessed since the 1990s and as recently experienced in the banking sector in Nigeria (Ofo, 2010). Olayiwola (2010) posit that poor corporate governance was identified as one of the major factors in virtually all known instances of financial institutions' distress in Nigeria. In agreement with the findings of this study, he found no consistent compliance and 
enforcement of the existing codes of corporate governance particularly with regard to prohibition of insider trading, regular publication of directors' dealings, transparent implementation of extraordinary transactions, equal access to information of all shareholders, role of board of directors, and reported consistent evidence of abuse of regulations regarding capital changes announcement with due warning and participatory opportunity and effective shareholder right enforcement by the courts. He concluded that although the institutions and the legal framework for effective corporate governance appear to be in existence, compliance with codes of corporate governance in banking/financial institutions in Nigeria and indeed its enforcement appears to be weak or completely nonexistent; that the CBN may have failed woefully to perform its oversight role as the banking supervision department of CBN might have compromised their roles.

In determining the significant difference in the firms' compliance with the key factors of corporate governance, it was found that there is no significant difference in firms' compliance with board composition, however, significant differences exist in the firms' compliance with firm size, ownership structure and disclosure between financial and manufacturing firms.

The results agree with the findings that the differences in the level of compliance between financial and manufacturing firms can be explained by certain arguments made by researchers. For instance, Adekoya (2011) posited that the Company and Allied Matters Act of 2004 derived from the Company and Allied Matters Decree of 1990 regulates and governs all corporate matters relating to corporations and non-profit organizations in Nigeria. The author argued that the CAMA was able to address some of the lapses and loopholes observed in the implementation of the 1968 Companies Act with the setting up of the Corporate Affairs Commission (CAC) with wider powers and more authorities than the Company Registrar which it replaced. It supervises, regulates and resolves all corporations' related matter in Nigeria.

However, in 2006, the CBN prescribed certain measures for mitigating the fifteen weaknesses that were observed in the 25 mega banks that emerged from the banking industry consolidation exercise of 2005, poor implementation and weak enforcement of the CBN corporate governance codes have prevented CBN from achieving its objectives of ensuring proper corporate governance in Nigerian banks. 
Vol. 2, No. 1 (Jun 2018); ISSN: 2602-5655

\section{Conclusion and Recommendations}

The results of this study have implications on the management of financial and manufacturing firms, the regulatory authorities in both sectors, the investors, the government and the economic growth of Nigeria. Improved corporate governance contributes to the country's competitiveness in attracting foreign investments as well as encouraging local entrepreneurs to invest in financial and manufacturing sectors in Nigeria. It will return lost confidence of shareholders in investment to stimulate the economy.

The government should be aware of the need to establish corporate governance codes for manufacturing firms in the same manner it was done for financial institutions. The regulatory bodies in both sectors should be empowered the more with legislative enactments to enforce compliance in the course of their oversight functions.

The results also create room for addressing issues of widespread corruption and poverty alleviation indexes. Development of private sector, currently viewed as the "engine of economic growth" will be encouraged and investment inflow into the country sustained.

\section{REFERENCES}

Akhalumeh, P., Ohiokha F. \& Ohiokha, G. (2011). Board Composition and Corporate Performance: An Analysis of Evidence from Nigeria Research Journal of Finance and Accounting, 2(4), 64 - 74

Akpan, N. (2007): "Internal Control and Bank Fraud in Nigeria". Economic Journal, Vol. 95, pp. 118-132

Ariff, A. M., Ibrahim, M. K. and Othman, R. (2007) "Determinants of firm level governance: Malaysian evidence", Corporate Governance, Vol. 7 Iss: 5, pp. $562-573$

Association of Chartered Certified Accountants (ACCA Australia and New Zealand) (2009). Disclosures on corporate governance. Retrieved November 9, 2013 from http://www2.accaglobal.com/pdfs/disclosure_corp_gov.pdf

Bantel, K. (1993). Strategic Clarity in Banking: Role of Top Management-Team Demography. Psychology Reports, 73, 1187-1203

Ben-Amar, W. and Ameur, B. (2006). Factor Explaining Corporate Governance disclosure quality: Canadian Evidence, Working Paper, http://www.business.illinois.edu/

Central Bank of Nigeria (CBN) (2006) "Code of Corporate Governance for Banks in Nigeria Post Consolidation". Retrieved February 12, 2011. http://www.cenbank.org/out/publications/bsd/2006/corpgovpostconso.pdf 
Dionco-Adetayo, E. (2011): Guide to Business Research and Thesis Writing, Ibadan, Rasmed Publications Ltd Pp129 -130

Ettredge, M., Johnstone, K. M., Stone, M. S. and Wan, Q. (2011). The Effects of Firm Size, Corporate Governance Quality, and Bad News on Disclosure Compliance Federal Government of Nigeria (2004): Companies and Allied Matters Act, Abuja, Government Press.

Greuning, H.V. and Bratavonic, S.B. (2003): Analyzing and Managing Banking Risk - A Framework for Assessing Corporate Governance and Financial Risk $\left(2^{\text {nd }}\right.$ ed.) The World Bank, Washington D.C. pp 287 - 304

Haat, M. H., Abdul Rahman, R. and Mahenthiran, S. (2008), "Corporate Governance,Transparency and Performance of Malaysian Companies", Managerial Auditing Journal, Vol. 23, No. 8, pp. 744778

Hartono, U., Subroto, B., Djumahir, G. and Irianto, G. (2013). Firm Characteristics, Corporate Governance and Firm Value. International Journal of Business and Behavioral Sciences, 3(8), 9 - 18.

Johnson, S., Boone P. Breach, A. and Friedman, E. (2002): "Corporate Governance in the Asian Financial Crisis". Journal of Financial Economics, vol. 58 no.1-2, pp 141-186.

Khanchel, I. (2007). Corporate governance: measurement and determinant analysis, Managerial Auditing Journal, 22(8),740-760.

La Porta, R., Lopez-De-Silanes, F. and Shleifer, A.(2000): "Investor Protection and Corporate Governance", Journal of Financial Economics, vol. 58, no. 1-2, pp.87-95

Lazareva, O., Rachinsky A. \& Stepanov, S. (2010).Corporate Governance, Ownership Structures and Investment in Transition Economies: the Case of Russia, Ukraine and Kyrgyzstan.Retrieved November 2, 2013 from http://www.cefir.ru/papers/WP119.pdf

Michael, J. G., \& Hambrick, D. C. (1992). Diversification Posture and Top Management Team Characteristics. Academy of Management Journal, 35, 937.

Mohammed, F. (2006): "Impact of Corporate Governance on Banks Performance in Nigeria", Journal of Emerging Trends in Economies and Management Sciences, 3(3), 257-260.

Nader, F. B. (2010). Ownership Structure, Corporate Governance \& Company Performance. Speech given at BMG Family Business Forum - Thursday 17th June 2010 Institute of Directors, Waterloo Room, 116 Pall Mall, London. Retrieved November 2, 2013 from http://www.levantlp.com/Articles\%Ownership\%20structure\%20\%20corporate \%20 performance\%20FBN\%20BMG\%20London\%20Seminar\%20140610.pdf

Ofo, N. (2013) Corporate Governance in Nigeria: Prospects and Problems. Retrieved

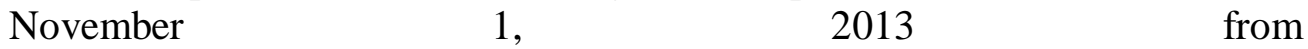
http://papers.ssrn.com/sol3/papers.cfm?abstract_id=1618600

Olayiwola, W. K. (2010). Practice and Standard of Corporate Governance in the Nigerian Banking Industry. International Journal of Economics and Finance, 2(4), 178 - 189 
Omoye S. A. and Eriki, P. O. (2013). Diversity in board ethnicity and firm performance: An empirical investigation of selected quoted firms in Nigeria. African Journal of Social Sciences, 3(4), 35-45

Ponnu, C.Y. (2008): "Corporate Governance Structures and the Performance of Malaysian Public Listed Companies", International Review of Business Research Papers, 4(2). March 2008, 217-230.

Pricewaterhouse Coopers, Indonesia and the Jakarta Stock Exchange (2009): "Corporate Governance", 2009 Report on Institutional Investor Survey Jakarta.

Shelton-Colby, S. (2000). The role of disclosure in strengthening corporate governance and accountability. The Third Meeting of the Russian Corporate Governance Roundtable. Retrived November 9, 2013 from http://www.oecd.org/corporate/ca/corporategovernanceprinciples/1930319.pdf Governances in Nigeria, Abuja.

Shleifer, A. and Vishny, R. (2000): "A Survey of Corporate Governance". Journal of Finaince, 52 (2) pp $737-783$.

Shonubi, A. (2003): Corporate Governance : An Investors Perspective. The Nigerian Accountant: Journal of Institute of Chartered Accountants of Nigeria, Vol. 6 No 1 January / March, (Lagos) pp $54-58$

Siciliano, J. (1996). The Relationship of Board Member Diversity to Organizational Performance. Journal of Business Ethics, 15,1313-1321.

Simons, T., and Pelled, L. (1999). Understanding Executive Diversity: More than Meets the Eye, Human Resource Planning , 22, 49-51

Watson, E., Kumar, K., and Michaelsen, L. (1993). Cultural Diversity's Impact on Interaction Process and Performance: Comparing Homogeneity and Diverse Task Groups. Academy of Management Journal, 36, 590-603.

World Bank (2009): World Development Report. World Bank Group.

Yeung, B. (2000): Comment in Concentrated Corporate Ownership, Morck RK (ed.) University of Chicago Press: 292-294.

Zahra, S.A. (1996): "Governance, Ownership and Corporate Entrepreneurship: The Moderating Impact of Industry Technological Opportunities", Academy of Management Journal Vol. 39 pp. 1713-1735

Zhuang, J. (1999). Some conceptual issues of corporate governance. EDRC Briefing Notes Number 13 [Online] Available: ww.adb.org/ Documents/Books/Corporate_Governance/Vol1/ chapter2.pdf. 